Portland State University

PDXScholar

$12-1973$

\title{
Black Content in Schools: a Model of Black Content in a School of Social Work's Curriculum
}

\author{
Dorothy L. Baker \\ Portland State University \\ Alexander Richberg \\ Portland State University \\ Isaac White \\ Portland State University
}

Follow this and additional works at: https://pdxscholar.library.pdx.edu/open_access_etds

Part of the Higher Education and Teaching Commons, and the Social Work Commons Let us know how access to this document benefits you.

\section{Recommended Citation}

Baker, Dorothy L.; Richberg, Alexander; and White, Isaac, "Black Content in Schools: a Model of Black Content in a School of Social Work's Curriculum" (1973). Dissertations and Theses. Paper 2100.

https://doi.org/10.15760/etd.2098

This Thesis is brought to you for free and open access. It has been accepted for inclusion in Dissertations and Theses by an authorized administrator of PDXScholar. Please contact us if we can make this document more accessible: pdxscholar@pdx.edu. 
BLACK CONTENT IN SCHOOLS

A Model of Black Content in a School of Social Work's Curriculum

by

Dorothy L. Baker

Alexander Richberg

Isaac White

This research project has been financed by a curriculum development grant from the Western Interstate Commission for Higher Education.

Research Advisor: Kay Toran Assistant Professor Portland State University School of Social Work

December, 1973 
TABLE OF CONTENTS

Copy of WICHE Award Letter i

Acknowledgements . ii

Preface iif

Scope and Method of Study $\quad \cdots 1$

Methodology : : 1

Limitations of the Study . . 2

Findings 3

Proposed Models . 13

Conclusion $\quad 26$

$\begin{array}{ll}\text { Footnotes } & 27\end{array}$

APPENDIX

Mini Workshop Folder 29

Questionnaire for A.D.C. Recipients 30

Questionnaire for Workshop Participants. . 33

Sequence Bibliographies

Human Behavior \& Social Environment 37

Social Research $\quad 43$

Social Welfare Policy 45

Social Work Practice , 52 


\section{Acknowledgements}

This study would not have been possible without the complete cooperation of the administration and staff of the Albina Multi-Service Center. We are particularly indebted to Leon Harris, former Manager of the Center in which our study was conducted.

Also, we are deeply indebted to the many social work practitioners and consumers in the Model C1ties area who willingly participated in the research.

We particularly want to thank Kay Toran, Research Advisor, for her early support and encouragement. She gave us the courage, determination and assistance to pursue this study. We particularly appreciate her assistance in every phase of the study, including the collection of data, critical readings, and general editing. Her assistance has not been confined to advising, but has transcended to include discussion of ideas and concepts presented in this project. 
Preface

This research was undertaken in response to the many questions raised by Black social work students concerning the need for Black content to be included in the social work curriculum at Portland State University. Black students at social work institutions throughout the country are presently attempting to develop a curriculum that will improve the delivery of social services in the Black community. Therefore, we have developed in the following pages a rationale and a suggested model for the introduction of appropriate Black content into the social work curriculum.

The words of Herbert Aptekar, Dean of the School of Social Work at University of Hawaii, are especially relevant in this regard. He recently stated that there are five main parties in any curriculum reconstruction endeavor:

...the student body, the instructional staff, the professional school as a whole (including its curriculum committee, administrative officers, and non-faculty advisory groups), the University at large, and the community and society of which all of the above are separate parties. 1

Significantly, Dean Aptekar puts its importance in the informal curriculum (what students learn on their own) as we11 as in the formal one: 
It may seem to be granting too big a role to say that they should play a central part in changes in the curriculum, but is it? If one recognizes that the essential purpose of the curriculum is to develop a generation of professionals who have a capacity to contribute to the profession, then one must raise the question, where and when do they start contributing? Certainly they cannot start as passive recipients of the knowledge and wisdom of their elders. They must start as actual givers of what they bring in their role as students. 2

This philosophy represents essentially the basics from which this research project was initiated. This project was undertaken by these researchers during their second year of study for the Master of Social Work degree at Portland State University School of Social Work.

The primary purpose of this study is, in general, to inform schools of social work of a method to include Black content within their curricula, and in particular to sensitize the faculty at Portland State University to the importance of including Black content into the school's curriculum.

In this research design, a select population was used as well as a specific body of knowledge from the Human Behavior and Social Environment sequence to develop a model to introduce Black content in the social work curriculum. 
This research project is an exploratory study of the need for Black content to be included in the curricula of schools of social work. This study stems in part from the researchers' desire to sensitize the faculty and student body at Portland State University to a deeper understanding of the cultural, psycho-socio, socio-psycho, and historical attributes of the Black population in order to:

1. Improve the delivery of social services to the Black community.

2. Improve the professional competence of the school's future graduates.

This study also reflects a significant concern set forth by the Council on Social Work Education concerning ethnic minority content in the social work curriculum which states that each:

school of social work must make a special continual effort to enrich its program by providing racial, ethnic, and cultural diversity in its student body and at a11 levels of instructional and research personnel, and by providing corresponding. educationa1 support. 3

This study will be reported in three parts. The first part consists of an analysis of data which was a result of a questionnaire administered to recipients of Aid to Dependent Children who received services at the Albina Multi-Service Center. The questionnaire surveyed their attitudes toward schools of social work training future professionals. The second part consists of an analysis of a workshop which surveyed attitudes of social work practitioners in the Model Cities area regarding the need to include Black content in schools of social work curricula. Part three is a proposed course content model for a Human Behavior and Social Environment sequence and also a model for the integration of Black content in the Social Research, Social Policy, and Social Work Practice sequences. A critical examination and review of literature that can be used to teach this content is included in the appendix.

Methodology

Data was gathered from three different sources. In June, 1973, a questionnaire was designed to be administered to recipients of Aid to Dependent Children who receive social services at the Albina MultiService Center in Northeast Portland. During the months of July and August, planning was underway at Portland State University to conduct a mini workshop entitled, "Black Content in the 
Soctal Work Curriculum." Throughout the months of June, July, and August of 1973, the researchers were also reviewing literature that could be used to begin development of Black content in the social work curriculum at Portland State University.

Figures representing the total population of families who are receiving Aid to Dependent Children were obtained from the manager of the Children's Services Division at the Albina MultiService Center. At the time of the survey, there were two thousand one hundred and twenty-seven families $(2,127)$ receiving A.D.C. of that total population, a random sample of one hundred A.D.C. recipients were given a questionnaire to complete while visiting the Center during the month of September.

On September 7, 1973, a mini workshop of social work practitioners was held at the Albina Multi-Service Center. The practitioners participating in the workshop were randomly selected from a list of practitioners employed in the Model Cities area of Northeast Portland. A random sample of thirty practitioners were invited to attend the workshop.

Throughout the data collection the research staff held a number of joint meetings in order to pool notes and information, check individual impressions, and attempt to systematize data as well as impressions.

Limitations of the Study

The major limitations of the study may be summarized in two categories: those having to do with the scope and method of the study and those having to do with the methods and time employed for gathering and analyzing data. These limitations should serve as overall guidelines for the interpretation of the data collected as well as factors to be considered in drawing any conclusions from the findings.

The several limiting factors are:

1. The scope of the study was limited by the selection and size of the population surveyed. It was confined to a random sample of one hundred recipients of Aid to Dependent Children receiving services at the Albina Multi-Service Center, which serves the Model Cities area in the city of Portland, Oregon.

2. The review of the literature examined to develop the course content model in this study is limited to a specific body of knowledge due to a lack of research and curriculum development in this general area. 
3. Finally, the method used to gather data, i.e., the choice of a paper and pencil questionnaire excluded an important variable which we failed to consider when designing the study. A measurable portion of the population surveyed was considered illiterate, which required the researchers to administer the questionnaire verbally.

Findings

Description of Sample

At the time the study was conducted there were a total of three thousand four hundred and forty-eight $(3,448)$ families receiving public assistance. Of these families, two thousand one hundred and twenty-seven $(2,127)$ families were receiving Aid to Dependent Children.

A random sample of one hundred families who received Aid to Dependent Children were administered questionnaires related to whether or not there is a need for Black content in social work education. Of the one hundred families surveyed, eighty-two (82) families responded. of these families, 8.4 percent were males and 91.5 percent were females. The respondents' ages ranged from sixteen to fifty years with the median age being 26.7 The age and sex distribution of the respondents is illustrated in Table $I$.

TABLE I

Age and Sex Distribution of Respondents

\begin{tabular}{cccccc}
\hline Years of Age & \multicolumn{2}{c}{ Females } & \multicolumn{2}{c}{ Males } & Total \\
\hline $16-20$ & 22 & $26.8 \%$ & \multicolumn{2}{c}{$0-$} & 22 \\
$21-25$ & 20 & 24.4 & $: 1$ & $1.2 \%$ & 21 \\
$26-30$ & 17 & 20.7 & 2 & 2.4 & 19 \\
$31-35$ & 3 & 3.7 & 1 & 1.2 & 4 \\
$36-40$ & 7 & 8.5 & & $-0-$ & 7 \\
$41-45$ & 3 & 3.7 & 2 & 2.4 & 5 \\
$46-50$ & 3 & 3.7 & 1 & 1.2 & 4 \\
\hline
\end{tabular}


Percentages in Table I were rounded off indicating the total percentage as being 99.9 percent. The true sum of the percentage is equal to 100 percent.

The marital status of these families is shown in Table II. of the families surveyed, the highest percentage of the families were single-parent families.

TABLE II

Marital Status of A.D.C. Families

\begin{tabular}{lcc}
\hline Marital Status & Number of Respondents & Percentage of Respondents \\
\hline Single & 38 & $46.3 \%$ \\
Widow & 6 & 7.3 \\
Separated & 18 & 22.0 \\
Married & 9 & 11.0 \\
Divorced & 11 & 13.4 \\
\hline
\end{tabular}

Table III represents the educational status of the eightytwo families participating in the study. 40.7 percent of the families had attained grade levels ten through eleven, while only 31 percent of the families were high school graduates or above.

TABLE III

Educational Status of Families with Aid to Dependent Children

\begin{tabular}{lcc}
$\begin{array}{c}\text { Educational } \\
\text { Leve1 }\end{array}$ & $\begin{array}{c}\text { Number of } \\
\text { Respondents }\end{array}$ & $\begin{array}{c}\text { Percentage of } \\
\text { Respondents }\end{array}$ \\
\hline $0-5$ Grades & 5 & $7.0 \%$ \\
$6-9$ Grades & 11 & 13.4 \\
$10-11$ Grades & 33 & 40.2 \\
High School Graduate & 26 & 31.0 \\
$1-3$ Years of College & 7 & 8.5 \\
College Graduate & 0 & 0.0 \\
\hline & $\mathrm{N}=82$ & $100.0 \%$
\end{tabular}


Analysis of Data

This part of the study has been designed to survey attitudes of social work consumers and social work practioners concerning the need for Black content in social work education. This analysis will be divided into two parts. The first will include the responses of the recipients of Aid to Dependent Children, and the second will include the responses of social work practitioners. These responses are listed in several categories: Black Content in Social Work Education, Black Family Life, and Living Conditions in the Black Community, Black Clients and Non-Black Social Workers, and The Recruitment of Black Social Work Students and Faculty in the Schools and the Profession of Social Work Education. The following report of findings includes only the responses of A.D.C. recipients.

In examining the aspect of Black Content in Social Work Education, our findings show a significantly high percentage of respondents agreeing that schools of social work should include Black content in the curriculum as well as teaching courses in Black history. 100 percent of the respondents agree that schools of social work should include Black content in the curriculum while 97.6 percent agree that social work' students should take classes in Black history. These findings support the need for schools of social work to include Black content in social work education.

Black Family Life

Black content in social work education should include the life experiences and living conditions of the Black family. The respondents were asked to respond to the following statements concerning the distinction between White and Black family life in America :

1. Black family life is different than White family life.

2. Blacks experience different life experiences than Whites.

3. A Black child raised in Black family develops differently than a White child raised in a white family.

Tables IV through VI indicate the responses of the respondents to the above statements.

TABLE IV

A.D.C. Families' Responses to the Statement:

"Black family life is different than White family life."

\begin{tabular}{ccc}
\hline Type of Response & Number of Respondents & Percentage of Respondents \\
\hline Agree & 76 & $92.7 \%$ \\
Disagree & 6 & 7.3 \\
\hline & $\mathrm{N}=82$ & $100.0 \%$ \\
& $-5-$
\end{tabular}


TABLE V

A.D.C. Families' Responses to the Statement:

"Blacks experience different life experiences than Whites."

Type of Response Number of Respondents Percentage of Respondents

\begin{tabular}{lrc}
\hline Agree & 75 & $91.4 \%$ \\
Disagree & 7 & 8.6 \\
\hline & $\mathrm{N}=82$ & $100.0 \%$
\end{tabular}

TABLE VI

A.D.C. Families' Responses to the Statement:

"A Black child raised in a Black family develops

differently than a White child raised in a White family."

Type of Response Number of Respondents Percentage of Respondents

\begin{tabular}{lrc}
\hline Agree & 75 & $91.4 \%$ \\
Disagree & 7 & 8.6 \\
\hline & $\mathrm{N}=82$ & $100.0 \%$
\end{tabular}

The above findings show that a very small percentage of the respondents disagree that Black family life is different than white family life, and that Black experience different life experiences than Whites. Of the respondents who disagree that Black family life is different from White family life, 3.6 percent of the 8.6 percent were in the 40--50 age range. This age range represents the older respondents among the A.D.C. families participating in this study. $91.4 \%$ of the respondents agree that living conditions in the Black community are different than conditions in other communities.

Black Clients and Non-Black Social Workers

The question of Black and non-Black social workers working with Black clients is of considerable interest to the profession of social work. In this study, we sought to ascertain the preference of Black clients to Black or non-Black social workers. $89.1 \%$ of the respondents agree that Black clients would be better off if they had Black caseworkers while $10.9 \%$ disagree with the statement. $80.5 \%$ of the respondents agree that non-Black social workers do not work effectively with Black clients, and $19.5 \%$ disagree with the statement. This is illustrated in Table VII.

TABLE VII

A.D.C. Families' Responses to the Statement:

"Non-Black social workers do not work effectively with Black clients."

\begin{tabular}{ccc}
\hline Type of Response & Number of Respondents & Percentage of Respondents \\
\hline Agree & 66 & $80.5 \%$ \\
Disagree & 16 & $19.5 \%$ \\
\hline & $\mathrm{N}-82$ & $100.0 \%$
\end{tabular}


Recruitment of Black Faculty and Students in Schools of Social Work

The data in Tables VIII and IX strongly support the need for the recruitment of Black faculty and students in social work education. 98.8 percent of the respondents agree that schools of social work should employ Black teachers, and 98.8 percent also agree that the field of social work needs more Black social workers. This is illustrated in Tables VIII and IX.

\section{TABLE VIII}

A.D.C. Families' Responses to the Statement:

"Schools of social work that train social workers should employ Black instructors."

\begin{tabular}{lcc}
\hline Type of Response & Number of Respondents & Percentage of Respondents \\
\hline Agree & 81 & $98.8 \%$ \\
Disagree & 1 & 1.2 \\
\hline & $\mathrm{N}=82$ & $100.0 \%$
\end{tabular}

TABLE IX

A.D.C. Families' Responses to the Statement:

"The field of social work needs more Black workers."

\begin{tabular}{lcc}
\hline Type of Response & Number of Respondents & Percentage of Respondents \\
\hline Agree & 81 & $98.8 \%$ \\
Disagree & 1 & 1.2 \\
\hline & $\mathrm{N}=82$ & $100.0 \%$
\end{tabular}

The findings from the questionnaire indicate that consumers of Aid to Dependent Children are of the opinion that Black content should be integrated within curricula of schools of social work.

To determine whether this is also a dominant theme among social work practitioners the mini workshop was planned to focus on the topic, "Black content in social work education at Portland State University." The workshop took place at the Albina Multi-Service Center in Portland, Oregon, September 7, 1973. The participants included social work practitioners, graduate social work students, and agency representatives.

An informal introduction dealing with the rationale and purpose of the workshop was given by Kay Toran, Assistant Professor of Social Work at Portland State University. Three graduate social work students from Portland State University, Dorothy Baker, Alex Richberg, and Isaac White, were facilitators of the workshop group discussion. 
The workshop discussion was focused on the following questions:

What is Black content?

How should it be integrated into the curriculum?

Who should be responsible for the implementation?

Should there be a time schedule for the implementation of Black content in social work education?

The highlight of the discussion group was the identification of several issues that appear to be pertinent to social work education at Portland State University. The general issues discussed were as follows:

1. That Black people are African people and that Black behavior be defined from a historical experience;

2. That institutional racism, capitalizm, imperialism, and colonialism are all forms of.oppression that contribute to the social problems that are experienced by Black clients;

3. That the social problems that confront Black people from day to day are problems that were created and developed by a system that has historically oppressed and exploited Black people;

4. That present medical and psycho-analytical modesl of social work practice, emphasize the disorganization and pathology of the individual. They inclusively fail to deal with the disorganization and pathology of the larger social, economic, and political system. It is this oppressive condition that prevents the total liberation of Black people;

5. That the nature and function of Black content in social work education would require structural changes within the total system of social work education.

In addition to these issues the discussion group identified, as major obstacles in social work education at Portland State University, problems surrounding the recruitment and retention of Black faculty and students, and the development of funding resources for the implementation of Black content.

Though the discussion centered around these problem areas, solutions to these concerns were not the major products of the discussion.

Several suggestions and strategies for the implementation of Black content in social work education were presented at the end of the workshop discussion. These suggestions will be further discussed in the conclusion of this report. 
The sample of thirty soclal work practitioners in the Model Cities neighborhood were selected randomly and malled questionnaires concerning the need for Black content to be included in social work curricula. Of the thirty questionnaires mailed, a total of twentythree were completed and returned. 65.1 percent of these practitioners were males and 34.9 percent were females. The practitioners ranged from 25 to 59 years of age with the median age being 36.8 years. 82.7 percent of them were Black and 17.3 were White. The age and sex distribution of the social work practitioners is illustrated in Table $\mathrm{X}$.

TABLE X

Age and Sex Distribution of Social Work Practitioners

\begin{tabular}{lccccc}
\hline Years of Age & \multicolumn{2}{c}{ Female } & \multicolumn{2}{c}{ Male } & Tota1 \\
\hline $25--29$ & 1 & $4.4 \%$ & 6 & $26 \%$ & 7 \\
$30--34$ & 1 & 4.4 & 3 & 13 & 4 \\
$35--39$ & 2 & 8.7 & 3 & 13 & 5 \\
$40--44$ & 0 & $-0-$ & 1 & 4.4 & 1 \\
$45--49$ & 1 & 4.4 & 2 & 8.7 & 3 \\
$50-54$ & 0 & $-0-$ & 0 & $-0-$ & 0 \\
$55--59$ & 3 & 13.0 & 0 & $-0-$ & 3 \\
\hline
\end{tabular}

$\mathrm{N}-23$

Table XI represents the educational status of the twentythree practitioners in this study. 82.6 percent of the practitioners have attained postgraduate level education.

TABLE XI

Educational Status of Social Work Practitioners

\begin{tabular}{|c|c|c|}
\hline $\begin{array}{l}\text { Educational } \\
\text { Levels }\end{array}$ & $\begin{array}{c}\text { Number of } \\
\text { Practitioners }\end{array}$ & $\begin{array}{l}\text { Percentage of } \\
\text { Practitioners }\end{array}$ \\
\hline Some College & 3 & $13.0 \%$ \\
\hline College Graduate & 1 & 4.4 \\
\hline Postgraduate & 19 & 82.6 \\
\hline & $\mathrm{N}=23$ & $100.0 \%$ \\
\hline
\end{tabular}


The following findings include the responses of the social work practitioners and their attitudes toward the need to include Black content in social work education

100 percent of the social work practitioners agree that schools of social work should make a special effort to include Black history within the curriculum as a requirement. These findings also support the contention that schools of social work also should include Black content in their curricula.

95.6 percent of the social work practitioners agreed that Black family life is different than White family life and that Blacks experience different life experiences than Whites, while 4.4 percent disagree. This is illustrated in Tables XII and XIII.

TABLE XII

Social Work Practitioners' Responses to the Statement: "Black family life is different than White family life."

\begin{tabular}{|c|c|c|c|c|}
\hline $\begin{array}{l}\text { Type of } \\
\text { Response }\end{array}$ & $\begin{array}{l}\text { Number of } \\
\text { Respondents }\end{array}$ & $\begin{array}{c}\text { Black } \\
\text { Practitioners }\end{array}$ & $\begin{array}{l}\text { White } \\
\text { Practitioners }\end{array}$ & $\begin{array}{l}\text { Percentage of } \\
\text { Respondents }\end{array}$ \\
\hline Agree & 22 & 18 & 4 & $95.6 \%$ \\
\hline Disagree & 1 & 1 & 0 & $4.4 \%$ \\
\hline & $N=23$ & & & $100.0 \%$ \\
\hline
\end{tabular}

TABLE XIII

Social Work Practitioners' Responses to the Statement: "Blacks experience different life experiences than Whites."

\begin{tabular}{lcccc}
\hline $\begin{array}{l}\text { Type of } \\
\text { Response }\end{array}$ & $\begin{array}{c}\text { Number of } \\
\text { Respondents }\end{array}$ & $\begin{array}{c}\text { Black } \\
\text { Practitioners }\end{array}$ & $\begin{array}{c}\text { White } \\
\text { Practitioners }\end{array}$ & $\begin{array}{c}\text { Percentage of } \\
\text { Respondents }\end{array}$ \\
\hline Agree & 22 & 18 & 4 & $95.6 \%$ \\
Disagree & 1 & 1 & 0 & 4.4 \\
\hline & $\mathrm{N}=23$ & & & $100.0 \%$
\end{tabular}

A high percentage of social work practitioners also agreed that a Black child raised in a Black family develops differently than a White child raised in a White family. (See Table XIV.)

The findings shown in Table XIV indicate that a high percentage of the social work practitioners also agree that life experience and living conditions in the Black community are different than iffe experiences in other communities. One of the unique 
differences that exist in the Black community is the special dialect. All of the social work practitioners agree that social workers should be aware of language differences when working with Black clients.

TABLE XIV

Social Work Practitioners' Responses to the Statement:

"A Black child raised in a Black family developes differently than a White child raised in a White family."

\begin{tabular}{lcccc}
\hline $\begin{array}{l}\text { Type of } \\
\text { Response }\end{array}$ & $\begin{array}{c}\text { Number of } \\
\text { Respondents }\end{array}$ & $\begin{array}{c}\text { Black } \\
\text { Practitioners }\end{array}$ & $\begin{array}{c}\text { White } \\
\text { Practitioners }\end{array}$ & $\begin{array}{c}\text { Percentage of } \\
\text { Respondents }\end{array}$ \\
\hline Agree & 20 & 16 & 4 & $87.0 \%$ \\
Disagree & 3 & 3 & 0 & $13.0 \%$ \\
\hline & $\mathrm{N}=23$ & & $100.0 \%$
\end{tabular}

95.6 percent of the social work practitioners agree that social services in the Black community do not adequately meet the needs of Black clients. This finding strongly suggests that new methods of social work intervention are needed in the delivery of social services to Black clients. 100 percent of the social work practitioners surveyed supported the need for schools of social work to develop new methods of social work intervention techniques with Black clients.

17.3 percent of social work practitoners disagree with the statement that most Black people would be better off if they had Black casseworkers, while 82.7 percent of social work practitioners agree to this statement. The 17.3 percent that disagree are all Black social work practitioners within the median age range of the sample. This finding is illustrated in Table XV.

TABLE XV

Social Work Practitioners' Responses to the Statement:

"With things as they are, most Black people would be better off if they had Black caseworkers."

\begin{tabular}{lccccc}
\hline $\begin{array}{c}\text { Type } \\
\text { of } \\
\text { Response }\end{array}$ & $\begin{array}{c}\text { Number } \\
\text { of } \\
\text { Respondents }\end{array}$ & $\begin{array}{c}\text { Black } \\
\text { Practi- } \\
\text { tioners }\end{array}$ & $\begin{array}{c}\text { White } \\
\text { Practi- } \\
\text { tioners }\end{array}$ & $\begin{array}{c}\text { Percentage } \\
\text { of } \\
\text { Respondents }\end{array}$ & $\begin{array}{c}\text { Median Age } \\
\text { of } \\
\text { Respondents }\end{array}$ \\
\hline Agree & 19 & 15 & 4 & $82.7 \%$ & 36.2 \\
Disagree & 4 & 4 & 0 & 17.3 & 39.4 \\
\hline & $N=23$ & & & $100.0 \%$ &
\end{tabular}


All of the social work practitioners agree that the social work profession needs more Black practitioners and that schools of social work that train social workers should employ more Black instructors. These findings support the need for the recruitment of the retention of Black faculty and students in schools of social work education.

This research project set out to prove the need for Black content, to be included in the curriculum of schools of social work. Both surveyed groups, A.D.C. recipients and practitioners, indicated significantly that this content should be integrated into the curriculum.

The results of the survey indicate also that the age, sex and race vartables had no significant influence on the responses of the consumers or the practitioners.

Based on the results of this study, it appears that there is a need for Black content to be included in social work education programs. Because of this need, the following model has been designed as a means of integrating this content into the curriculum. 
For many years, schools of social work have been operating under the assumption that social workers should be competent to practice in any community. However, schools have not included in their curriculum the necessary content to ensure this competency within the Black community.

Presented in the following pages are course models which can be used to develop courses in the four major sequences in schools of social work. Primary emphasis will be on the effects of institutional racism, colonialism, and capitalism on the social, psychological, economical, and political development of the Black family and the Black community.

\section{Proposed Models}

The majority of the social issues and problems that confront Black Americans today are a direct result of their being an oppressed minority within Anglo-American society.

Black Americans in this country are the greatest victims of racist attitudes and practices....

Racism continues to deny the Black man the vital recognition of human dignity; equal protection of the law; equal access to opportunity; equal justice in the judicial process; equal housing; equal health opportunities; and equal educational opportunities in integrated settings. 4

Its implications for social work education are expressed in the following examples:

1. There is little difference between the ghetto and the old African colonies. The military is the police, the mercantile is the White ghetto storekeeper who exploits the community and takes the money back to the suburbs, and the missionary is the social worker who helps the Blacks to 'adjust' to their state of oppression. 5

2. Social work theory still insists that the socio-psychological environment of Black Americans is the same -- or is certainly only a shade different from -- the environment of White Americans. In spite of the continuous hostility heaped on Blacks solely because they are Black (in addition to all the normal pressures of life), most social work theorists persist in contending that Blacks do not develop some unique responses or do not have different needs or physical requirements from Whites Such theorists arrogantly submit that this body of response is - not worth attention equal to that given the body of 
response is not worth attention equal to that given the body of socio-psychological knowledge undergirding social work curricula for work with clients (often called the "general public"). 6

3. ...in working with Black clients White practitioners tend to relate themselves only to the responsible Negroes--those who agree to behave White and think White. When a Black person deviates from this expectation, he immediately tends to be thrust into the role of militant with all the anxiety-producing characteristics that White people have assigned this role. In reality, such a response says, "I will love you and help you if you agree to continue to hate yourself!"7

The crucial factor involved in social work education is the Black person's perception of social work. Within the Black community there is deep antagonism towards socịal work and social workers, and a repudiation of it, along with the rest of White society, as an instrument of oppression. 8

Indeed it is the contention of this research group that social work education should become more sensitive to this antagonism that exists among the Black population. This simply means that social work education must become sensitive to the strengths, problems, needs, and the total 1iberation of Black people.

Therefore, it must include the necessary curriculum that will expose students to the skills necessary for the liberation of Black people. It must prepare students who will be committed to social change and have the committment and competence to deal with social problems and institutional racism. For Portland State University this can partially be achieved by including Black content in four basic sequences, and developing content that can also be taught in courses outside these sequences. Listed below is a model for integration of Black content into the Social Environment and Human Behavior sequence, the Social Welfare Policy sequence, and the Social Work Practice sequence, and the Social Research sequence.

Content which shall be included in the four sequences will relate to any cultural knowledge about the Black experience that both complements and enhances significant elements already included in the sequences: Human Behavior and Social Environment, Social Work Practice, Social Work Policy, and Social Work Research.

The Human Behavior and Social Environment sequence can use a comparative approach to define commonalities and differences in: patterns of socialization, family structure, cultural values and: 
orientation as well as class differences among Blacks, minorities, and Whites. Students will develop awareness and understanding of the stereotypes, fallacies, myths, and misconceptions about the Black population which have been perpetuated by soctal scientists and practitioners over the course of time.10

Special emphasis will be given in this sequence to the fact that Blacks were brought to this country as slaves and that the Judeo-Christian White society, seeking a rationale for the enslavement of human beings, cited the blackness of the slaves as indicative of inherent inferiority. Thus 'Black' was equated with inferiority consequently excluding the Black man from the major institutions within this society.11 Consequently this experience has had devastating effects on the social and psychological development of the Black family and the Black community.

The Human Behavior and Social Environment sequence described below is an introductory course designed to increase students' awareness of the culture, values, and history of the Black population.

SEQUENCE: Human Behavior and Social Environment

COURSE TITLE: Human Behavior and Adaptation in the Black Family

This is an introductory course on the study of the origin, history, culture, and adaptation of the Black family in AngloAmerica.

Introduction:

The primary focus of this course will be to explore, evaluate, and examine the culture, history, language, values, and norms of the Black family. It is intended that particular attention will be given to racism as a vital social problem affecting the psyche as weil as the socio-economic status of the Black family. Primary attention will be given to adaptive behavior patterns, ego development, and coping mechanisms developed by the Black family as survival tools in a pathological and dysfunctional society.

Objective:

The broad objectives of this course are:

1. To provide information about the historical development of racism and the Black family.

2. To demonstrate the strengths of the Black family in spite of the adverse effects of slavery and discrimination. 
3. l'o examine the cultural and environmental factors that influence behavior and personality development of the Black family.

The learning objectives for students are:

1. To demonstrate an understanding of the Black family's long history of denial, exploitation, and oppression.

2. To demonstrate an awareness of the cultural factors affecting the psychological development of the Black family.

3. To demonstrate an understanding of racism and its impact on ego development and maturation.

4. To be able to identify adaptive behavior patterns, and coping mechanisms developed by the Black family in response to environmental stresses.

The diagram below represents the model from which this course can be taught. This model presents a socio-psychological approach to assessing personality development and socio-economic status of the Black family.

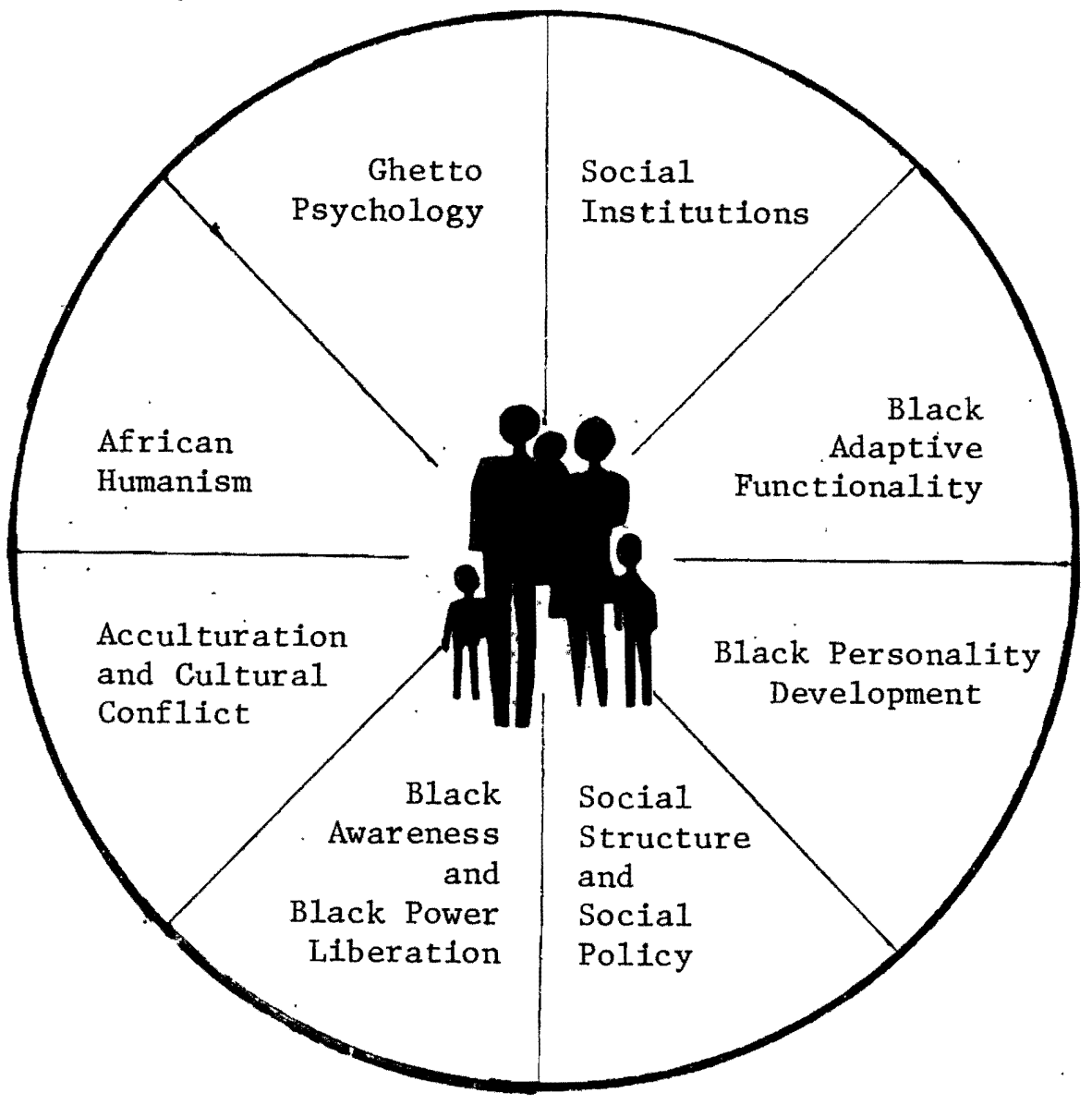


Listed below is an explanation of the concepts included in this mode1. These concepts will be developed further during the instruction and implementation of the proposed course.

\section{African Humanism}

African Humanism is a concept that describes and explains the Black family's early African way of life. It provides a historical understanding of Black family life, Black value system, and Black behavior. African Humanism offers an insight into the African nature of the Black family structure, patterns of behavior, and Black life style. To understand this concept is vitally necessary if one is to understand the significance of African culture in the life style of Black Americans.

\section{Ghet to Psychology}

Ghetto psychology is the science that deals with the inferior schools, substandard housing, menial jobs, unemployment, delinquency, narcotic addiction, poor health care, homicide, and adult crime in the Black community. The reason for these conditions can be traced to the social pathology of a society that needs to maintain these conditions. Social work education must expose students to the realities of such a psychology in order to ensure that students are competent to deal with these realities.

\section{Black Personality Development}

Black personality development must be understood, analyzed, and assessed from the early slave experience which allenated, colonized, and oppressed Black people. Social work education must recognize that societal economic forces and the resultant institutional racism may be a major factor that creates stress in Black communities and limits the realization of potential in Black individuals. 12

Leon Chestang points out the significant effect of institutional racism on Black personality development. He defines injustice, inconsistency and impotence as three crucial conditions that affect character development in the Black personality. For example, he describes the effect of impotency on character development as follows:

The fruits of impotence are a loss of autonomy, a diminished sense of self-worth, and low self-esteem. The feeling of impotence generates fear, inadequacy, and insecurity, which transcend all classes of Blacks. These feelings, while more behaviorally apparent among poor Blacks, are no less real to Blacks of middle and upper income levels. This is true only because our 
society assigns all Black people to a single category, regardless of attainments, income, or any.criteria by which it extends recognition. A Black person's potential. for ego enhancement is always reduced by the need to question whether recognition represents an acknowledgement of his contribution or the expediency of adhering to guide lines and meeting quotas.13

Social work education needs to expose students to a11 the forces affecting Black development to ensure that students use the most appropriate intervention technique when treating and understanding Black clients.

\section{Black Power}

Black Power is a concept that was carved and coined for Black people by. Black people. It describes an awakening, an awareness. a consciousness, and a movement by oppressed Black people. The quest for Black power denotes that the Black population will no longer accept tokenism or any form of oppression by Anglo America. Black people are seeking 1iberation and power to plan and control their own destinies. The concept Black Power includes many things, but for social work education it can best be described to mean the following: Rroviding social work students with the necessary content in the social work curriculum that will prepare them to be advocates for Black people in the pursuit of Black power--equality!

\section{Acculturation and Cu1tural Conflict}

This concept will expose students to the dynamics of cultural fusion in a dominant "Anglo World." The social acculturation process among Black Americans is not necessarily self-wished, nor selfimposed but is rather a process forced upon Blacks by an Anglo society that fails to accept, know, and understand Black Americans.

\section{Black Adaptive Functionality}

There are three characteristics of Black behavior which are key elements in understanding the above concept. These three characteristics are as follows:

1. The history of enslavement, exploitation, and discriminatory practices against the Black family.

2. The development of coping mechanisms by the family for survival under these oppressive conditions.

3. The adaptation of the Black family to survive and remain functional in this society denotes great strength. A11 of 
the three characteristics above make up the concept, "Black Adaptive Functionality" and will be further examined to increase social work students' awareness of functional adaptive behavior patterns developed by Blacks in a dysfunctional society.

\section{Social Institutions}

The concept of social institutions and their influence on the Black family must be understood and approached from a dual operational context. Dual operational context includes the influences of major institutions in the wider White society and major institutions in the Black community that affect the psychology, health, economy, education, and the total welfare of the Black family. For example, the church is considered one of the basic social institutions in the Black community. It has served as a model for reinforcing positive self concept and self esteem in the Black family, while social institutions outside of the Black community have historically excluded the Black family from equal participation and active involvement in their operations. It is vitally necessary that social work students begin to understand the interplay that is apparent between these two groups' major institutions.

\section{Social Structure and Social Policy}

Social structure and social policy are concepts that must be analyzed to determine the influence or impact each has on Black family life and the community. Social workers need to have some knowledge and insight into how social structure (the Black church; care of the young, elderly; values) affects life styles, and decision-making of Black people. In addition, workers need to be cognizant of social policy which may be functional for one group, but be quite destructive and dysfunctional to the growth and development of Black individuals. Social work education must prepare students to critically examine these areas to be effective in working in the community. 
The Social Welfare Policy sequence will include a historical perspective of the values and systems of racism and capitalism and its impact on the economic security and profile of the Black community. It will also include conceptual knowledge about the national, social, and economic policy which accounts for the plight of Black people. 14 Topics of basic significance in this sequence will include the interaction of the Black community with social welfare systems; the history of Blacks in social welfare; and the history and impact of Black organizations on social policy. Special attention will be given to racist policies and practices and their impact on the survival of the Black community.

Content dealing with social policy that is a result of, or reaction to racism shall also be included in this sequence. An example of this can be seen in education "compensatory" programs. These programs are geared toward building the skills and changing the attitudes of ghetto children. These programs are not designed to force structural changes within the school system which contribute to the problems the children are experiencing in school. Another example of social policy that deals with the symptom rather than the cause is in community mental health programs. Within these programs the tendency is for the clinician to attempt to strengthen the Black family through working with egos and psyches rather than dealing with the sociological problems that are a result of racist practices--unemployment, improper inadequate housing, improper nutrition, and poor health. 15 This sequence will expose students to the impact of social policy on Blacks in general and on poor Blacks specifically.

SEQUENCE: Social Welfare Policy

COURSE TITLE: The Black Community and Social Policy

This is a course on the development of social welfare policy programs and services in the Black community.

Introduction:

This course will attempt to sensitize students to the linkage between poverty, policy, and race.l It will focus on an examination of social policy and how it effects the economic, political, and social development of the Black community. Primary emphasis will be on the Black community's perception of racism in terms of social policy and their response to racism through institutional change, community control, and alternative proposal for liberation and justice. 
Course Objectives:

The broad objectives of this course are:

1. To acquaint students with the myth of national social and economic policy on the alleviation of poverty.

2. To demonstrate the interrelatedness of racism and capitalism on current welfare policy.

3. To examine the current trends in policies and social services program and how they affect the welfare of the Black community.

The learning objectives of this course are:

1. To demonstrate an understanding of the history of institutional racism as a structural control in national policy that affects the Black community.

2. To demonstrate an awareness of the alternative programs, proposals, and organization development by the Black community in response to social policy and practices.

3. To increase understanding and awareness of social policy that attempts to de-ghettoize the Ghetto.

This model can be implemented with an introductory course taught in the Social Work Policy sequence, entitled "The Black Community and Social Policy." The model from which this course can be taught is represented in a following diagram. (See next page.)

The model will increase students awareness of the role and function of social policy and programs in the Black community. Programs in the model will be evaluated and anlyzed according to the stated objectives in the proposed course content model. This model will examine the influences and the development of poverty, social policy and programs on the welfare of the Black community. This means that special consideration will be given to social policy and racism and its effects on the social, political and economic development of the Black community. This model will expose students to the realities of social policy in the Black community and will introduce students to new models developed by Blacks as a means of dealing with these realities, such as the Nation of Islam, the National Welfare Rights Organization, and the Republic of New Africa. The model represents a programmatic attempt to avoid dealing with racism. 


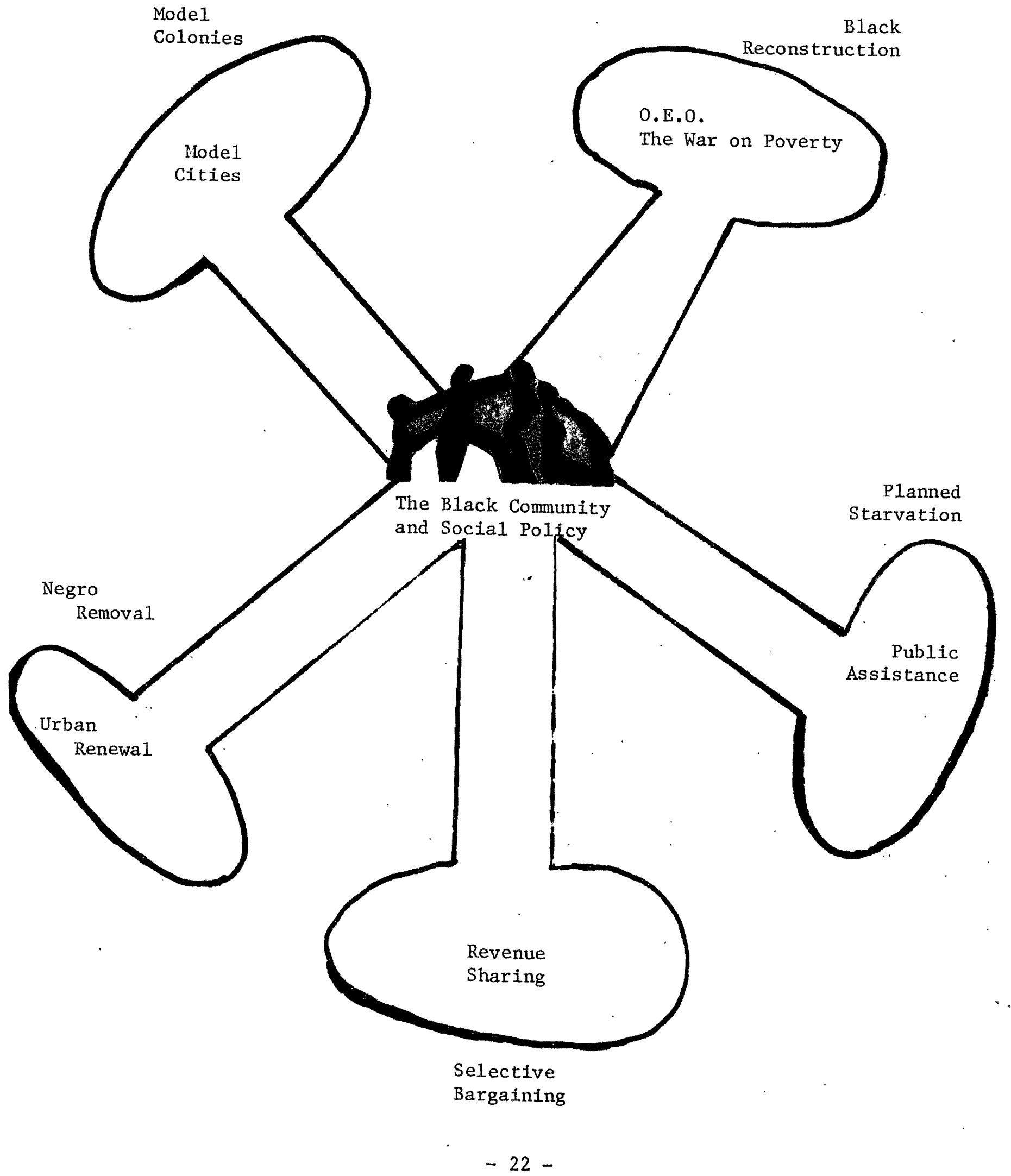


The Social Work Practice sequence will include knowledge from the Human Behavior and Social Environment sequence. This sequence will expose students to treatment modalities and interventions based on liberation rather than adjustment. Liberation will encompass exposing students to the skills and knowledge necessary for the total enrichment of Black family life. J. Chun and H. Stanback believe that,

all of these skills should speak to changing, eliminating, and creating systems that cause or can solve problems of Black people. It must be understood that the target for change is not simply within the Black community.16

Therefore, this sequence should expose students to the following themes for the treatment of Black clients:

a. The appropriate determination of goals for Black clients;

b. New means of forming treatment contracts with inner city clients;

c. The effect of race and culture of the client upon treatment planning and methods;

d. Issues presented by assigning a White worker or a Black worker to a Black client;

e. New modes for professional behavior when working with Black clients;

f. The impact of communication patterns of these clients upon diagnosis and treatment;

g. Critique of theoretical formulation and practice currently employed with such clients, and

h. New treatment strategies for work in the inner city. 17

The above themes can be implemented by requiring that students participate in a third day of field practice. The third day of field practice will consist of a seminar designed to provide students with necessary skills and techniques for treating Black clients.

Listed below is a proposed seminar developed for a third day of field practice at Portland State University. 
SEMINAR: Social Work Intervention with Black Clients

The topic of the seminar will be "Social Work Intervention With Black Clients." The seminar will combine discussion of case histories, case studies, and process recordings of Black clients. (The seminar will include Black clients, and Black professionals, and paraprofessionals as lecturers.)

The primary focus of this seminar will be to explore new treatment modalities and intervention with Black clients. It is intended that particular attention will be given to the examination of social problems and societal pathology as vital factors in establishing treatment plans for Black clients. Thus, although there will be some discussion of literature with a broader coverage, an experiential approach to problem solving with Black clients will be the primary thrust of this seminar. Video taping, on-site visits to the Black community, and rap sessions with Black clients will be some of the key tools used for instruction in this seminar.

The seminar will be organized as follows:

1. The first six weeks of the quarter, there will be general discussions and reading relating to social work intervention with the Black client.

2. Meetings during the remaining part of the quarter will be devoted to video taping, and rap sessions with Black clients. To facilitate this, each student will be expected to submit a proposal for a strategy for social work intervention with Black clients.

3. In addition to the above, each student will participate in a group project in the Black community that will increase his understanding of life experiences and living conditions in the. Black community. follows :

The learning objectives for students in this seminar are as

1. To demonstrate an awareness of the effects of race and racism on the helping interview.

2. To identify the socio-economic factors and forces that interfere with treatment planning for Black clients.

3. To demonstrate an awareness of cultural differences that affect diagnosis and treatment process of Black clients. 
4. To demonstrate an awareness of self and one's own reaction to racial differences.

SEQUENCE: Research

Research is a vitally important sequence within the School of Social Work. The research experience in education lays the foundation for research as a professional. All students need to be taught proper research techniques that will enable them to do a meaningful research practicum or thesis which is a requirement for the degree.

Schools of social work will need to make it mandatory that a significant number of research projects include studies which are completed in the Black community.

A course model per se for the research sequence cannot be developed. This is largely related to the fact that most research practicums are individually concelved. However, it becomes the schools' responsibility to direct students to those areas of 1 ife where there exists a dearth of research data. This is certainly true of Black communities. It is of great importance that sutdents have a proper understanding of Black life before they begin research in a Black community. One only needs to be reminded of the fallacious Moniyhan report18 to understand the problems that may arise in attempting to research a group without adequate knowledge and background about that group.

There are currently many hypothesis which can be tested by students that relate to the growth and development of Black individuals; Black family life; Black community development; social programs; economic development; political power or powerlessness in the Black community and on and on and on. It seems that any graduate school which is not having research completed in these and other areas related to the urban population is seriously remiss in its responsibility to students, the community, and the profession. 


\section{Conclusion}

The findings in this research study support conclusively the hypothesis that there is a need for Black content to be included in the curriculum of schools of social work. Course models have been developed by this research group to give guidance and direction to those schools of social work which are planning to include this content in their educational program. The models, of course, represent only a beginning. Though a beginning, the models do provide a framework from which comprehensive courses in Black content can be taught.

Schools must realize that the models alone will not be sufficient to achieve the objective of making social work education more relevant, i.e., establishing a curriculum that is representative of the real world. In addition to the models, it is necessary that schools have a representative faculty as well as a representative student body. To be more specific, schools of social work must hire Black faculty and have a significant number of Blacks enrolled as students to insure that social work education is relevant and is addressing pertinent Black issues.

These recommendations are made as a result of the activity and involvement of this research group with recipients and practitioners. The need for Black content has been proven; the conclusion has been expressed. Now it is time for schools to act expeditiously and begin addressing that need. Hopefully, the proposed models will provide to those schools the knowledge necessary to be successful in this effort. 


\section{FOOTNOTES}

1. Black/Brown Coalition of Social Work Students,"The Introduction of Appropriate Black and Chicano Content into a Social Work Curriculum." University of Houston, School of Social Work, January, 1972.

2. Ibid.

3. Council on Social Work Education, Manual of Accrediting Standards, Library of Congress, U.S.A., Sowers Printing Co., p. 6.

4. Douglas, Joseph H., "Racism in America: A Continuing Crisis," National Conference of Christians and Jews, Inc., N.Y., N.Y., July, 1970, p. 14 .

5. Stiles, Evelyn, et al, "Hear it Like it Is," Social Casework, LIII, May, 1972, p. 293.

6. Funnye, Clarence, "The Militant Black Social Worker and the Urban Hustle," Social Work, Vo1. 15, No. 2, April, 1970, p. 10.

7. Shannon, Barbara E., "Implications of White Racism for Social Work Practice," Sacial Casework, Vo1. 51, No. 5, May, 1970, p. 275.

8. Ibid, p. 293.

9. Black/Brown Coalition of Social Work Students, op. cit., p. 5.

10. Ibid.

11. Council on Social Work Education, Black Task Force Report, Suggested Guides for the Integration of Black Content into the Social Work Curriculum, New York, Council on Soclal Work Education, 1973, p. 6 .

12. Ibid.

13. Chestang, Leon W., "Character Development in a Hostile Environment," Occasional Paper, No. 3, School of Social Service Administration, University of Chicago, November, 1972, p. 6.

14. Black/Brown Coalition of Social Work Students, op. cit., p. 6 .

15. Murase, Kenji, A Report on Ethnic Content in the Social Welfare Policy and Social Research, San Francisco State College. 
16. Annual Report of the Office of Student Affairs, The National Association of Black Social Workers, April, 1973, New York, Vo1. 1, No: 1, p. 3 .

17. Leigh, James W. "Ethnic Content in Field Instruction," a report presented at the Western Interstate Commission on Higher Education workshop on Minority Ethnic Content in the Social Work Curriculum, Idy11wild, California, December, 1971, p. 14.

18. Staples, Robert, The Black Family, Edited by Wadsworth Pub1ishing Co., Inc., Belmont, California, 1971. 
A P P E N D I X 


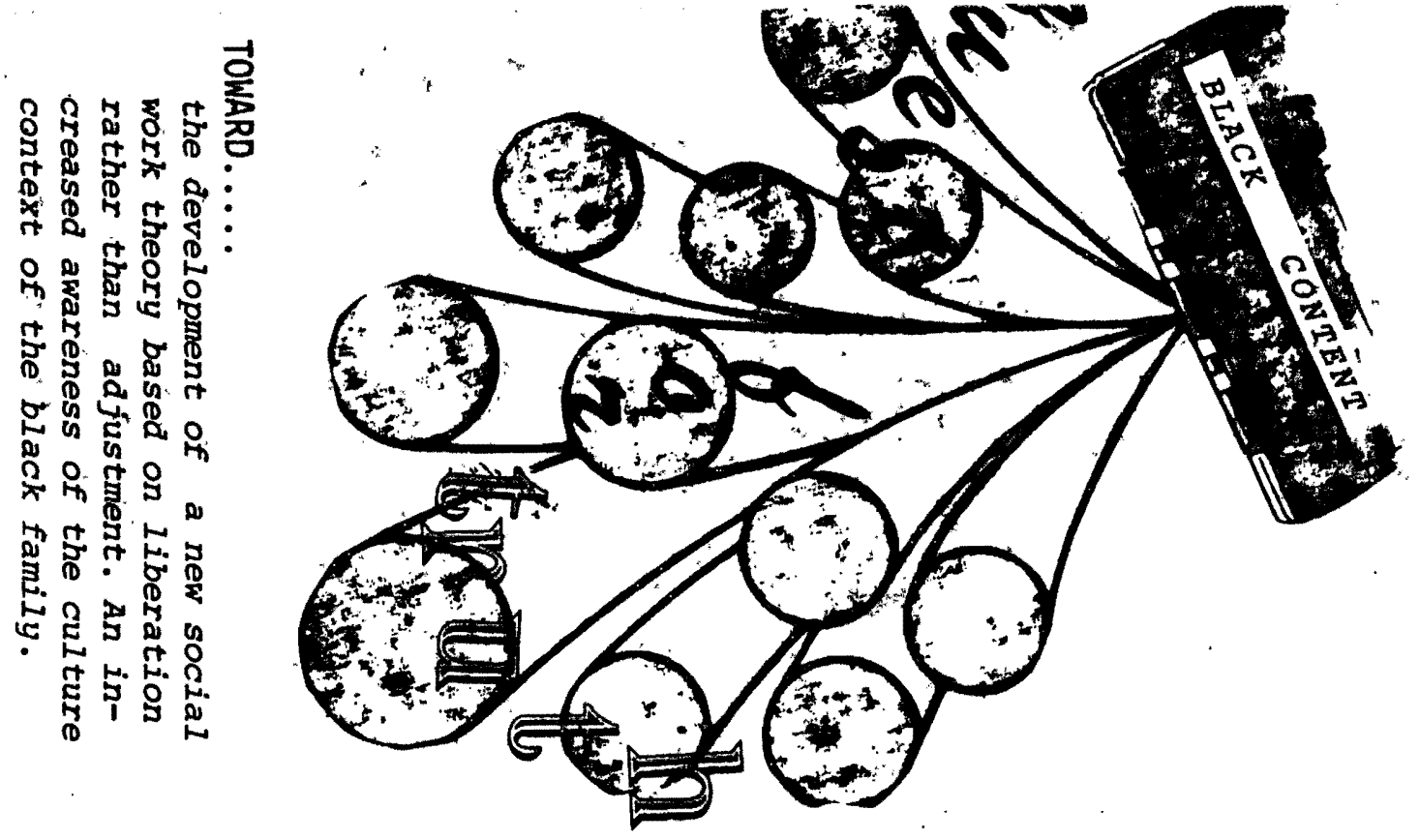

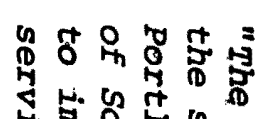

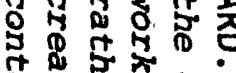

* 550

- क 50

a 4

ธุ

क्र है क

욱

蛙尔

o

550

N. . R.

营 15
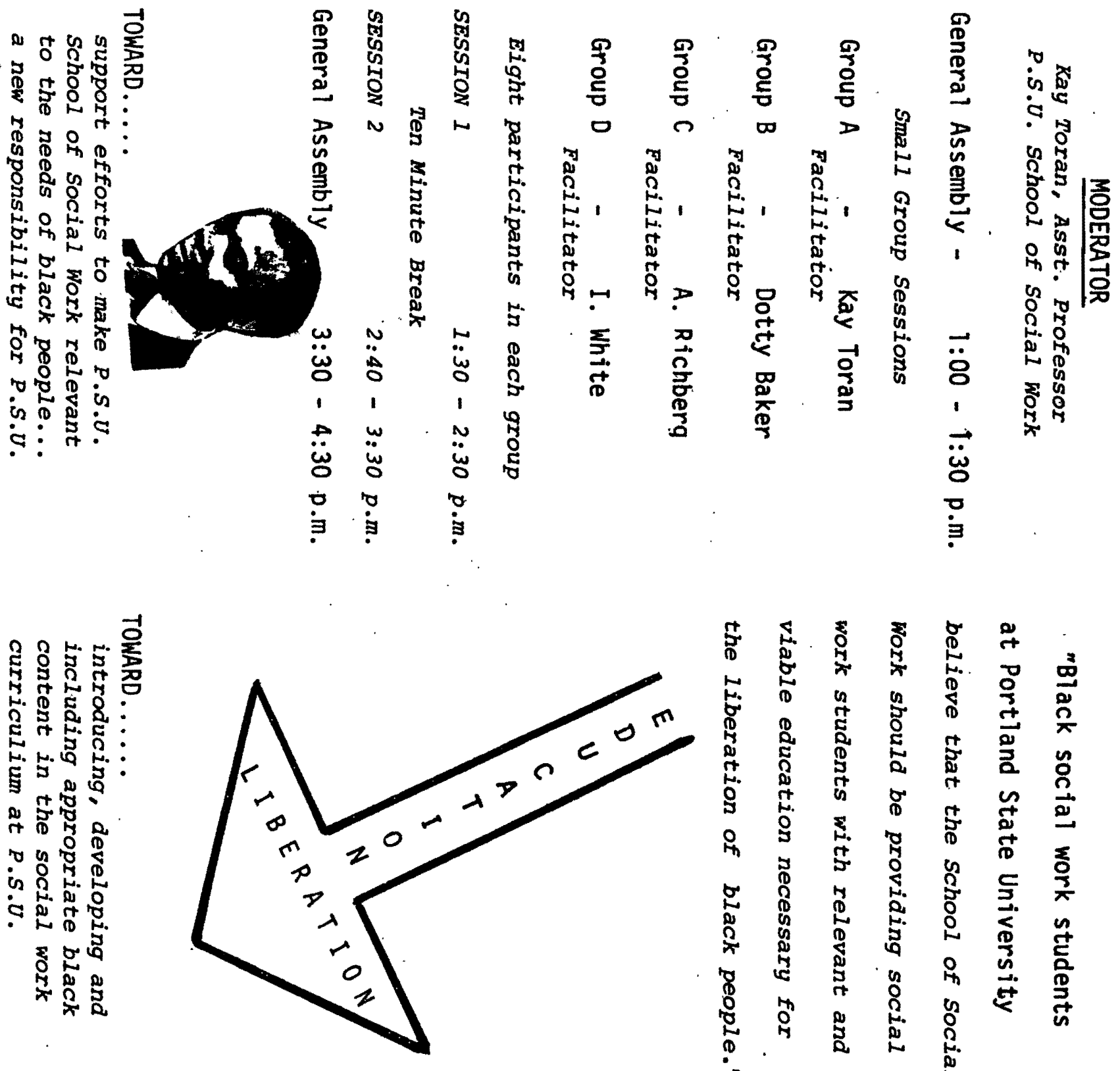

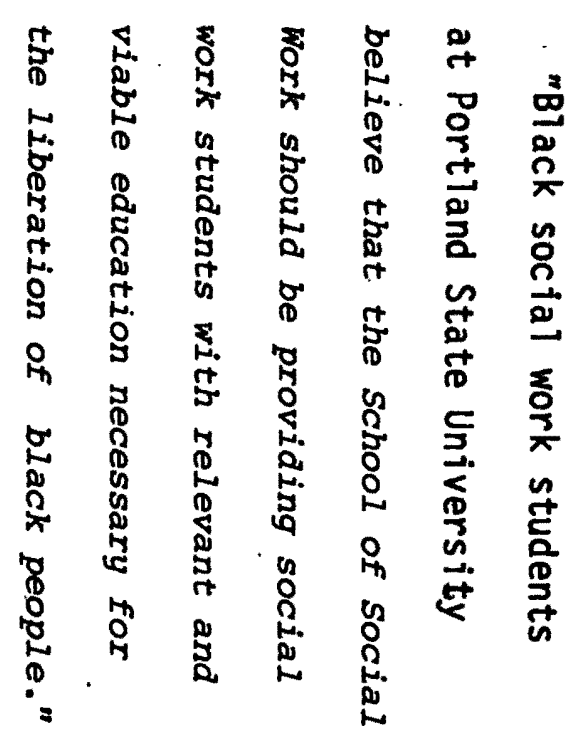

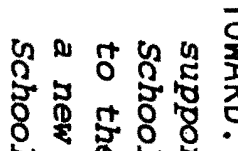

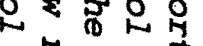

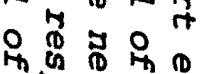

क马 क क

2. 世. 月 م.

क ज क क ज

怘芯

ํㅗㄴ

$\therefore$ के

员 D

-

is

$\begin{array}{ll}\stackrel{\omega}{\omega} & \omega \\ 0 & 0 \\ \dot{0} & 0 \\ \dot{\theta} & \dot{\theta}\end{array}$

จ

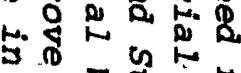

+4

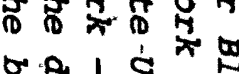

员员 1 员

रั

8 ษ

青워

เ. 0 ถ

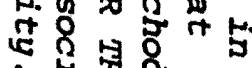

$=$ 赑要 
QUESTIONNAIRE / General Information

A. Age

B. Sex

1 Male

2 Female

C. Marital Status

1 Single

3 Widowed

5 Separated

2 Married

4 Divorced

D. Fthnic Background

1 Black

3 Chicano

5 Asian-American

2 White

4 Native American

6 Other

E. Are you currently employed?

1 Yes_ 2 No

3 If "Yes," what is your occupation?

4 If "No," what is your source of income?

F. What is your approximate monthly income?

1 Less than $\$ 200$

2 200--299

$3 \quad 300--399$

$4 \quad 400--499$

$5 \quad 500--699$

6. $700--899$

7900 or more

G. Are you affiliated with a religious organization?

1 Yes 2 No

H. If "Yes," what group?

I. What is the highest grade completed in school?

$$
\begin{aligned}
& 10--5 \\
& 2 \text { 6--9 } \\
& 3 \quad 10--11
\end{aligned}
$$

J. How many members are in your immediate family? 
Listed below are some statements which some people agree to and some disagree with. Please indicate to what extent you agree or disagree with the following:

1. Social workers should take classes in Black history.

$\begin{array}{ccrr}\text { Strong1y } & \text { Slight1y } & \text { S1ight1y } & \text { Strongly } \\ \text { Agree } & \text { Agree } & \text { Disagree } & \text { Disagree }\end{array}$

2. Schools that train social workers should make a special effort to teach Black content.

$\begin{array}{llrl}\text { Strongly } & \text { Slight1y } & \text { Slightly } & \text { Strongly } \\ \text { Agree } & \text { Disagree } & \text { Disagree }\end{array}$

3. Living conditions and life experiences in the Black community are different than conditions in other communities.

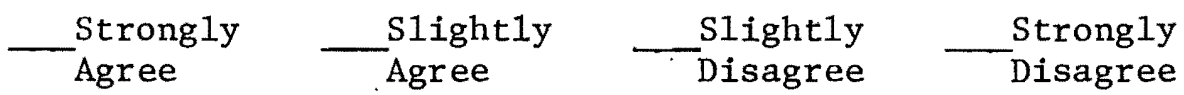

4. With things as they are, most Black people would be better off if they had Black caseworkers.

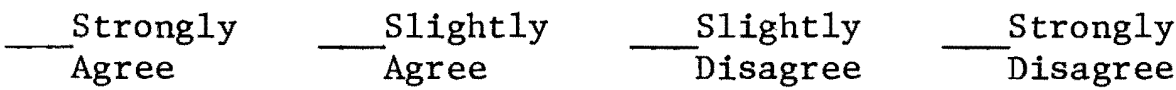

5. Non-Black social workers do not work effectively with Black clients.

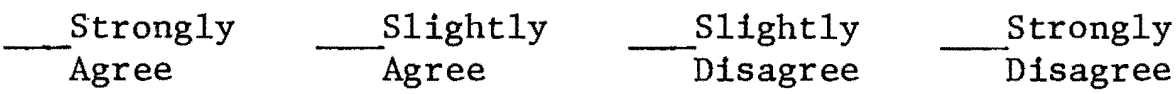

6. Black family life is different than White family life.

$\begin{array}{crcr}\text { Strongly } & \text { Slight1y Slightly } & \text { Strongly } \\ \text { Agree } & \text { Disagree } & \text { Disagree }\end{array}$

7. Blacks experience different life experiences than Whites.

$\begin{array}{llrl}\text { Strongly } & \text { Slightly } & \text { Slightly } & \text { Strongly } \\ \text { Agree } & \text { Agree } & \text { Disagree } & \text { Disagree }\end{array}$

8. A Black child raised in a Black family develops differently than a White child raised in a White family.

$\begin{array}{llrl}\text { Strongly } & \text { Slight1y } & \text { Slightly } & \text { Strongly } \\ \text { Agree } & \text { Disagree } & \text { Disagree }\end{array}$ 
General Information

A. Age

B. Sex

Male

Female

C. Position Title

Employer

D. Ethnic Background

Black

Chicano

Asian-American

E. Number of Years of College

Degree Received

Field or Major
White

Native American

Other

$\mathrm{IW} / \mathrm{cc}$

$8 / 9 / 73$ 
Listed below are some statements which some people agree to and some Alsagree with. Please indicate to what extent you agree or disagree with the following:

1. Social workers should take classes in Black history.

$$
\begin{array}{ccr}
\text { Strongly } & \text { Slightly Slightly } & \text { Strongly } \\
\text { Agree } & \text { Disagree } & \text { Disagree }
\end{array}
$$

2. Schools that train social workers should make a special effort to teach Black content.

\begin{tabular}{|c|c|c|}
\hline Strongly & Slight1y & S1ightly \\
\hline
\end{tabular}

3. Living conditions and life experiences in the Black community are different than conditions in other communities.

\begin{tabular}{|c|c|c|}
\hline Strongly. & Slightly & Slightiy \\
\hline & & Disagree \\
\hline
\end{tabular}

4. With things as they are, most Black people would be better off if they had Black caseworkers.

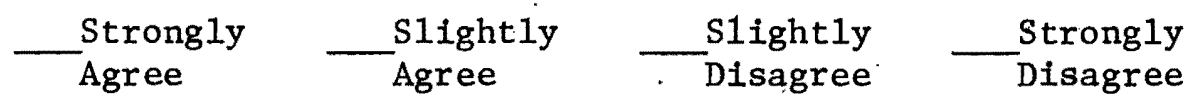

5. Black family life is different than white family life.

\begin{tabular}{|c|}
\hline Strongly \\
\hline
\end{tabular}

6. B1acks experience different 11fe experiences than Whites.

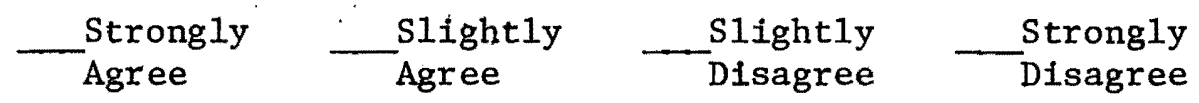

7. A Black child raised in a Black family develops differently than a. White child raised in a White family.

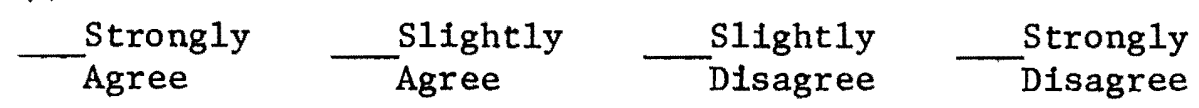

8. White social workers need to understand Black history in the U.S.A. to work effectively with Black clients.

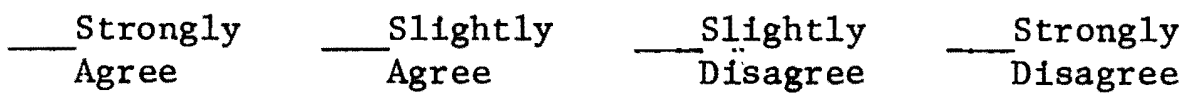


9. Present social service in the Black community does not adequately meet the needs of Black clients.

\begin{tabular}{|c|c|c|}
\hline Strongly & Slight1y & Slight1y \\
\hline Agree & Agree & Disagree \\
\hline
\end{tabular}

10. Non-Black social workers should be aware of language differences with Black clients.

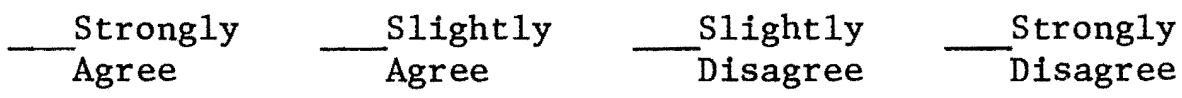

11. Social workers tend not to get involved with the Black community.

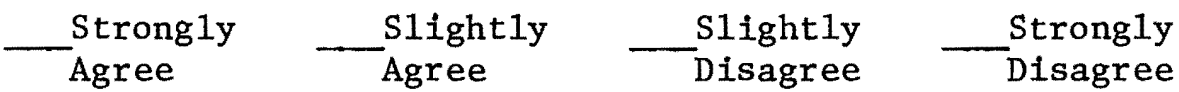

12. Schools of social work that train social workers should employ Black teachers.

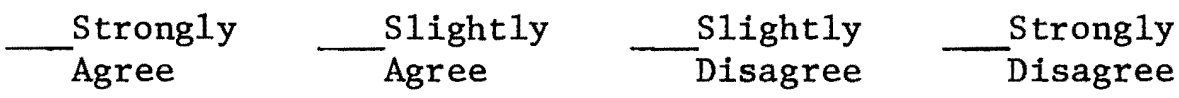

13. The field of social work needs more Black social workers.

$\begin{array}{llrl}\text { Strongly } & \text { Slightly } & \text { S1ight1y } & \text { Strong1y } \\ \text { Agree } & \text { Disagree } & \text { Disagree }\end{array}$

14. Schools of social work that train social workers should include Black clients to participate in classroom discussions, lectures, and rap sessions.

$\begin{array}{lll}\text { Strongly } & \text { Slightly } \\ \text { Agree } & \text { Slightly } & \text { Strongly } \\ \text { Disagree } & \text { Disagree }\end{array}$

15. An increased knowledge of the culture, values, and norms of Black people would make me more effective in working with Black clients.

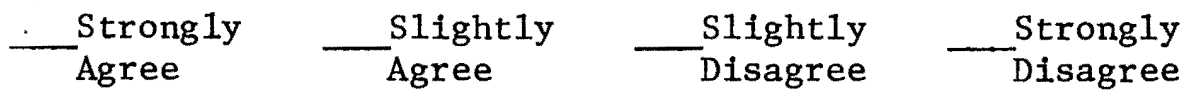

16. Schools of social work should develop new treatment modalities, interventions, and strategies for the treatment of Black clients.

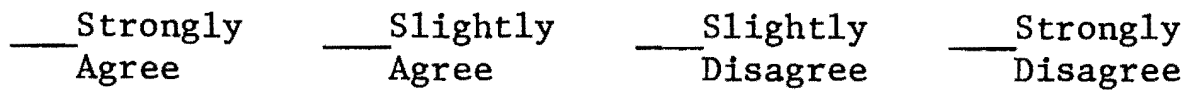


17. Schools of social work should make a special effort to develop awareness and understanding of the stereotypes, fallacies, myths, and misconceptions about the Black population.

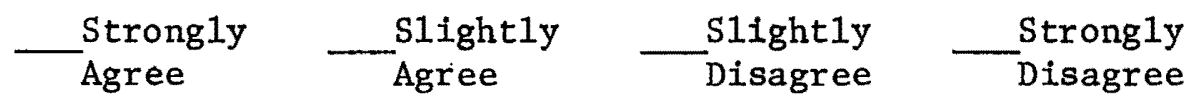

18. Participating in this workshop has been a different and rewarding experience for me.

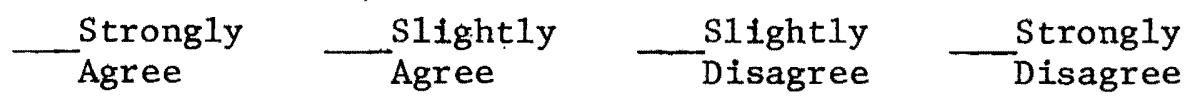

19. More workshops on the Black client would increase my knowledge and competence in working with Black people.

\begin{tabular}{|c|c|}
\hline angly & S1ightly \\
\hline Agree & Agree \\
\hline
\end{tabular}

$\mathrm{IW} / \mathrm{cc}$

$8 / 9 / 73$ 


\section{SEQUENCE \\ BIBLIOGRAPHIES}

****

Human Behavior and Social Environment

Socia1 Research

Social Welfare Policy

Social Work Practice 


\section{Bibliography}

for Human Behavior and Social Environment Sequence

1. Allen, William D., Africa, Sacramento, California, California State Department of Education, 1964.

A descriptive and analytical study of African culture and values. In this book Allen reviews different aspects of African life styles.

2. Aptekar, Herbert, A Documentary History of the Negro People in American States, New York: Citadel Press, 1968, Vols. I and II.

Volume I is a resource that gives an explicit documentary history of the Black man from colonial times to the Civil War.

Volume II is a description of the Black man's role in history from the civil war to the founding of the National Association for the Advancement of Colored People in 1910.

3. Baldwin, James, Nobody Knows My Name, New York, 1969.

Baldwin examines the problems facing Blacks in America. This book discusses the myths that Whites perpetuate about Blacks.

4. Banks, James A., March Toward Freedom: A History of Black Americans, Palo Alto, California, Fearson Publishers, 1970.

A chronological history of the Black American from African history to the Black revolts in the 1960's.

5. Banks, Jane A., and Grambs, Jean Dresden, Black Self-Concept; Implications for Educational Social Science, New York, McGrawHill Book Co., 1972.

Explores the various dimensions of Black self-concept to delineate ways in which the schools could enhance the self images of Black children. Also, to increase their academic achievement and emotional growth.

6. Bennett, Lerone, Jr., Before the Mayflower: A History of the Negro in American, 16--19, 1964, Baltimore, Penguin Books, 1967.

A Black journalist presents a unique account of the Black man's existance before the coming of the Mayflower. He traces the history of the Black man from Africa to the Civil Rights movement in America. Though not a scholarly achievement, it is both insightful and enlightening. 
7. Bennett, Lerone, Jr., Pioneers In Protest, Penguin Books, Inc., Baltimore, Maryland, 1969.

Portraits of such great Black pioneers as Crispees. Ahucks, Benjamin Banneker, Marcus Garvey, John Brown, etc. The author gives a description of Black pioneers and their contribution in the making of America. A great insight of Black consciousness, Black achievement, Black determination, and Black heroism.

8. Billingsly, Andrew, Black Familles in White America, Prentice Ha11, Inglewood, N. J., 1968.

A Black sociologist presents a penetrating analysis of the history, problems, and social situations of black families in White America.

9. Blake, Herman J., Racism at a Great University, 16, No. 5, March 1965.

Blake gives a comprehensive description of institutional racism . in educational systems in America. The author studies the effects of racism on the Black student both within the educational setting and life in general.

10. Boggs, James, Racism and the Class Struggle, New York, Monthly Review

A review of the civil rights from slavery to the present. The author traces the development of the revolutionary.movement from the struggle in the South to ghettos in urban cities of the North.

11. Breltman, George, By Any Means Necessary, Pathfinder Press, Inc., New York, 1970.

An excellent book on the political ideology and the movement of Black liberation in America. A great Black leader of the mid-60's, Malcolm X, reveals the evolution of Black consciousness, Black identity and White oppression.

12. Brown, Claude, Manchild in the Promised Land, New York, Macmillian, 1956.

Brown's autobigraphical novel reveals how life can be for a child growing up in Harlem ghetto. Describes vividly the various forms of oppression and adaptive behavior used to survive the experience. 
13. Cade, Toni, The Black Woman: An Anthology, New American Library, Inc., New York, 1970.

Black women speaking out on socio-economic, political issues concerning the role of Black women in Amertca. This book gives a vivid picture of the thinking of today's Black woman.

14. Chestang, Leon W., Character Development in a Hostile Environment, Occasional Paper, No. 3, November, 1972, Chicago, I11inois, School of Social Service Administration, University of Chicago.

This paper attempts to briefly outline a conceptual model for understanding Black character as it develops in response to society's assaults. An excellent explanation of the characteristic.responses of Black Americans as they experience injustice, inconsistency, and impotency in a hostile environment.

15. Cole, Robert, Children of Crisis: A Study of Courage and Fear, Little, Brown, \& Co., Boston, 1967.

The author discusses the effect of racism and segregation on the social and psychological development of Black children.

16. Conant, James, R., Slums and Schools, New York, McGraw-H 111 , 1961.

This author examines the many problems facing Black youth in ghet to schools. This book discusses the inadequate educational experience encountered by Black children in ghetto schools.

17. Conton, W. F., West Africa in History, George Allen and Win, Ltd. , 1965.

An exciting book that explains the way of life for Black men and women in West Africa approximately five thousand years ago. This book gives a history of the culture of West Africa. This book is important since it is believed that most Afro-Americans came from West Africa.

18. Cruse, Harold, The Crisis of the Negro Intellectual, New York, Marrow, 1967.

A summary and analysis of the history of Blacks in America. This book presents many theories of Black-White relationships, and gives special attention to the role of Black intellectuals in America. 
19. Daniel, Mannix and Malcolm, Lowley, Black Cargoes, A History of the Atlantic Slave Trade, Viking Press, New York, 1962.

An excellent review on the origin of slavery in America.

20. David, John, American Negro Reference Book, Englewood Cliffs, New Jersey, Prentice Hall, Inc., 1966.

An excellent account of the various problems that exist in America's ghettos.

21. Dollard, John, Cast and Class in a Southern Town, Garden C1ty, Double day, 1949 .

A White psychologist examines the social structure of a small southern town in the 1930's.

22. E11ison, Ra1ph, Invisible Man, New York, Random House, 1947.

An excellent novel that deals with the Black man's search for identity.

23. Franklin, John Hope, From Slavery to Freedom, 2nd Ed., N.Y., 1964.

A general discussion of slavery in the United States.

24. Freed, Leonard, Blacks in White America, Grossman Publishers, N. Y., 1970.

An excellent summary and analysis of the history of Blacks in America: The author presents a photographic description of what life is like for Blacks in White America.

25. Gains, Ernest. The Autobiography of Miss Jane Pittman, N. Y. Bantem Book Dia1.

A concise sketch of the life of a female Negro slave.

26. Genovese, Eugene D., The Political Economy of Slavery, New York, Pantheon, 1965.

A collection of studies on the economic reasons for slavery and the conditions of slave life in the South.

27. Geshwender, James, The Black Revolt, Englewood Cliff, New Jersey, Prentice Ha11, 1971.

A review of the Los Angeles riots of 1965. The author discusses 
how the increasing demands for justice by the Black population led to violence in an urban ghetto.

28. Greenberg, Jack, Race Relations and American Law, Columbia University Press, New York, 1959.

This book gives an excellent account of legal ramifications of racial policy in the American legal system.

29. Handlin, Oscar, The Uprooted Boston, Little, Brown, and Co., 1951.

A descriptive and analytical study of Negro life in the United States with a particular focus on conditions in urban cities that have large Black ghettos.

30. Huggins, Nathan I., Harlem Renaissance, N. Y., Oxford University Press, 1971.

This is an excellent historical account of the Harlen renaissance. The book is an evluation of the earlier Black artistic achievements, and the roles of Black intellectuals, reformers, and leaders.

31. Husbands, Ann, "The Developmenta1 Task of the Black Foster Child," Social Casework, Vo1. 51, No. 7, July, 1970.

An excellent article on the psychological growth, racial identity, and personality development of Black children. Included also, are good suggestions to assist caseworkers in their work with Black foster chlldren.

32. Hyland, Toney, The Castles of Elmina, Accra, Ghana, Ghana Museum and Monuments, Inc., 1971.

Included in this book is a short history of the forts and castles in Ghana. Many of these castles were used to house the African slaves before they were shipped to America.

33. Johnson, James Wellden, Black Manhattan, New York, Alfred A. Knopff, 1930.

An excellent discussion of life and problems of Black Harlen and its residents.

35. Joseph, Stephen M., The Me Nobody Knows, New York, Avon Books, 1969 .

A collection of writings by children of the ghetto in New York 
City, in an attempt to diminish the stigmas pinned on slum area children. Also gives a glimpse of the cognitive development of Black children in the ghetto.

36. Killens, John Oliver, Black Man's Burden, Trident Press, New York, 1955.

A Black author gives a personal account of the Black man's burdens in America. He evaluates the race problem to be a White problem.

37. King, Larry L., Confession of a Whitet.Racist, New York, Viking Press, Inc., 1971.

This book describes in great intensity, the life style, thoughts of a white racist, and the psychological as well as sociological effects of racist attitudes, myths, and distorted beliefs of White racists.

38. Knowles, Louis and Prewitt, Kenneth, Institutional Racism in America, Englewood Cliffs, N. J., Prentice.Ha11, 1969.

Discussion of implications of racism in America. 


\section{Bibliography}

for Social Research Sequence

1. Burkey, Richard M., Racial Discrimination and Public Policy in the United States, D. C. Heath and Company, Massachusetts, 1971.

This book examines and evaluates the nature of racial discrimination on public policy.

2. Clarke, Kenneth, Dark Ghetto: Dilemmas of Social Power, New York: Harper and Row Publishers, 1965.

An excellent study on the political, social, economic, and psychological ramifications of Black life in an urban ghetto.

3. Flax, Michae1 J., Blacks and Whites, Urban Institute, Washington, D. C., 1971.

Included in this book are the results of statistical data on the socio-economic status of Black and White families from 1968 to the present.

4. Ladner, Joyce, Tommorrow's Tomorrow, The Black Woman.

An excellent research study written by a Black female sociologist. Dr. Ladner examines the attitudes of young Black lowincome adolescent girls concerning marriage, education, Blackness, men, and other topics. She examines the Iife styles of Black women from a Black perspective, rather than from a pathological approach which many white researchers use in their studies of the Black family.

5. Rainwater, Lee. Behind Ghetto Wa11s: Black Families in a Federa1 Slum, Aldine Publishing Co., Chicago, 1970.

This book consists of research data obtained through studying the problems of a public housing project originally aimed at assisting the government agencies in developing more effective social welfare programs. However, emphasis soon shifted toward questions involving changes in the socio-economic system.

6. Slater, Jack,"Hypertension: Biggest Killer of Blacks," Ebony, Vo1. XXVIII, No. 8, June, 1973.

This study examines at length an illness found predominantly among Black Americans. It reveals statistical data which verifles the extent and effect of hypertension on Black people. 
7. Tabb, William K., The Political Economy of the Black Ghetto, W. W. Norton \& Co., Inc., New York, 1970.

A study of the Black ghetto and the economic factors which help to explain its origin and maintain its existence. Tabb also examines the impact of capitalism on the Ghetto and explores strategies for ending Black exploitation and elements of oppression within the economic and political system of the Ghetto.

8. U. S. Bureau of Census, The Social and Economic Status of the Black Population in the United States, U. S. Government Printing Office, Washington, D. C.

A collection of statistical data on the social and economic status of Black people in the United States.

9. Weaver, Robert, The Negro Ghetto, Russe11 Co., New York, 1967.

A study of Negro Iife experiences in a housing project in PruittIgoe, St. Louis, Missouri's Black community. The author provides a wealth of information on Black culture, adolescence and peer group relationships, marriage, and living conditions of Black Americans.

10. Youth in the Ghetto, Harlem Youth Opportunities Unlimited, Inc. New York: 1964.

This study is better known as the famous "Haryou-Act" report on Harlem. A study of the anger, rage, frustrations, and hostility of Black youth in a Harlem ghetto. 


\section{Bibliography}

for Social Welfare Policy Sequence

1. Berner, Lawrence, "Law, Income, and Barriers to Use of Health Service," New England Journal of Medicine, Vo1. CCLXXVIII, No. $10,1968$.

Examines the effects of racist medical policies on minorities and the poor.

2. Blauster, Albert P. and Robert L. Langrando, Clvil Rights and the American Negro: A Documentary History, New York, Washington Square Press, 1968.

Included in this book is an overview of Black Americans' encounters with injustice, prejudices, and discrimination in the U.S.A.

3. Block, Herman D., The Circle of Discrimination: An Economic and Social Study of Black Men in New York, New York, New York University Press, 1969.

This book identifies, analyzes, and documents the "circle of discrimination" that has led to the Black man's economic subordination in New York. Special emphasis is placed on employment opportunities, politics, and trade unions.

4. Boggs, James, Racism and the Class Struggle, New York, Monthly Review.

A review of the civil rights from slavery to the present. The author traces the development of the revolutionary movement from the struggle in the South to ghettos in urban cities of the North.

5. Brink, William and Louis, Harris, Black and White, New York Simon and Schuster, 1966.

Brink and Louis present a comprehensive description of institutional racism in the judicial system of America. This study concludes that the existence of discrimination is more difficult to prove since prosecutors, judges, and juries are less aware of and open with their own racism.

6. Burkey, Richard M., Racial Discrimination and Public Policy in the U.S., Massachusetts, D. C. Heath and Co., 1971. 
This is an excellent study of racial discrimination in America. This book presents a research project that will develop a theoretical perspective on the nature of racial discrimination in the U.S.A.

7. Carmichael, Stokely and Charles V. Hamilton, Black. Power: The Politics of Liberation in America, Random House, 1967.

Two Black authors explore the various meanings of Black Power in America. A real look at the political ideology of racism and its implications on Black liberation.

8. Caughey, John W. and Ernest R. May, Land of the Free, Pasadena, California, Franklin Publications, Inc., 1967.

This study examines the civil rights movement, and the role of Whites in the federal government.

9. Cleage, Albert B., Jr., Black Christian Nationalism, New York, William Morrow and Co., Inc. 1972.

This study examines the need for new directions for the Black church and the need for a new Christian nationalism.

10. Coleman, James S., Resources for Social Change: Race in the U.S., New York, John Wiley and Son, Inc., 1971.

This book provides a framework that will aid in describing and distributing resources (power) among Blacks in the U.S.A. The book raises basic questions and examines the power resources that Blacks can utilize. The author presents a foundation through which research can aid in bringing these changes about.

11. Davis, Angelia Y., If they Come in the Morning, Third World Press, Joseph Okpahn Pub.: Col, Inc., 1971.

The author gives a true description of American injustice to Blacks and discusses the hypothesis that all Black prisoners incarcerated are political prisoners.

12. Davis, David B., The Problem of Slavery in Western Culture, New York, Corne11 University Press, 1966.

This book is concerned primarily with the White communitiy's attitudes toward Blacks and the development of the legal structures that supported the slave system in the New World.

13. Donovan, John, The Politics of Poverty, New York, Pegasus, 1967. 
This book discusses the implications of the poor in the inner city taking control of programs that directly affect their lives. It also emphasizes that if dramatic changes are not forthcoming, the racial crisis is bound to deepen even though relief and employment programs be improved.

14. Douglas, Joseph, Racism in America: A Continuing Crisis, White House Conference on ChIldren and Youth, New York: National Conference of Christians and Jews, Inc., 1970.

A distinguised sociologist examines the growing threat of racism in American society. He deals with the dynamics of racism, its effects on the psyches as well as the socio-economic life of a nation and its implication on international affairs. He clearly defines the significant impact that racism has had on the Black American population.

16. Dye, Thomas R., The Politics of Equality, New York, Bobbs-Merril1 Co., Inc., 1971.

A unique study that deals with the history of the development of a racially stratified society, the patterns of political and social forces that maintain this society, and the political role of Blacks (and Whites) in meeting persistent demands for changes in the relative statuses of the two races. The author draws judiciously from the literature of sociology and economics as well as from political science in presenting a balanced view of the American Black's long and continuing search for ful1 equality.

17. Gayle, Addison, Jr., The Black Situation, New York, Horizon Press, 1970 .

This book acknowledges what is going on in the minds of thinking Black men in a White society, and its consequences for our time.

18. Ginger, Ann F., Minimizing Racism. In Jury Trials, Berkeley, 1969.

Examines the socia1, political, and legal implications of the trial of Huey Newton.

19. Greeley, Andrew, Why Can't They be Like Us, New York, Dutton, 1971.

Presents a critique on America's fallure to appreciate the importance of ethnic groups in American society.

20. Grier, George, Equality and Beyond, Chicago, Quadrangle Books, 1966. 
Discusses a common reality practice known as block-busting that has been used by real estate agents.

21. Haskin, James, Proflles in Black Power, New York, Doubleday and Co., Inc., 1972 .

Examines the meaning of the slogan "Black Power". as defined by eleven Black leaders who contributed to its development.

22. Hawley, Willis D., Blacks and Metropolitan Government: The Stakes of Reform, Berkeley, Institute of Government Studies, 1972 .

Examines the quest for reformation of the institutions that shape public policies for Black urban Americans.

23. Hickerson, Nathaniel, "Physical Integration is Not Enough," Journal of Negro Education, Spring, 1963.

This book deals with the racist educational policies of the public school system particularly the tracking system.

24. Jones, Edward H., Blacks in Business, New York, Grossett and Dunlap, Publishers, 1971.

A brief history of the Black businessman and guide to action. It is designed to give the reader a clearer understanding of the Black businessman and his problems, and suggestions for action.

25. Jordan, Winthrop, White Over Black: American Attitudes Toward the Negro, University of North Carolina Press, 1968.

This study is concerned primarily with the White community's attitude toward Blacks and the development of the legal structure that supported the slave system in the New World.

26. Kain, John F., Race and Poverty: The Economics of Discrimination, New York, Prentice-Hal1, Inc., 1969.

This study reveals the debilitating economic effects of racial discrimination in the labor market, in housing, and in education, and examines the attitudes of Blacks and Whites toward civil rights and integration.

27. Kalvin, Harry Jr., The American Jury, Boston, Little, Brown, \& Co., 1966.

This study discusses the inequality of the American judicial system. 
28. Kerner Riot Commission Report: Report of the National Advisory Commission on Civil Disorder, U.S. Government Printing Office, 1968 .

A report on the study of urban violence. An extensive review of the race riots in Detroit, Watts, and Newark.

29. Kerper, Karen, The New Movement: Power for the Powerless, New York, 1968.

Essays, quotes, and photos depicting life in America for the poor and the Black American. America divided itself into youth against maturity, rich against poor, Black against White--those who believe, and those who don't.

30. Lacy, Dan, The White Use of Blacks in America, New York, Atheneum, 1972 .

A review of the history of White racial politics. Recounts the politics of Whites toward Blacks in America from 1619 to the present; views and interprets the aggregate of laws, judicial decisions, racial etiquette, extra-legal violence, and personal attitudes that have marked 350 years. Examines the conflict between racial policy and American ideals of liberty and equality, pointing out that major changes in policy have only been achieved by force, or when Whites needed to use Blacks' change.

31. Lane, Robert E., Political Life, New York, The Free Press of Glencoe, 1960.

This study looks at the new non-partisan politics of the cities emphasizing efficiency and neutrality of officials. Consequently, city government has become highly professionalized and unresponsive to the opinions of any minorities.

32. Lincoln, Eric C., Is Anybody Listening to B1ack America?, New York Sealuiry Press, 1968.

Lincoln discusses how Americans perceive themselves and their place in society, and how they perceive each other across the barrier of race. It presents a spectrum of Black opinion and a spectrum of White response.

33. McDay, Claude, Harlem: Negro Metropolis, New York, E. P. Dutton, 1940.

The book focuses on the socio-economic problems of Negroes during the depression years. 
34. McIntire, Davis, Residence and Race, Berkeley, California, 1960,

Examines the racial discrimination in the purchasing and selling of houses to minorities. This study was done in Berkeley,

California.

35. Miller, Elizabeth W., The Negro in America: A Bibliography,

Cambridge, Mass., Harvard University Press, 1968.

An annotated list of over 3,500 books, documents, articles, and pamphlets on the Negro in history. Most of these articles were published since 1954. A valuable collection of resources on the study of Negro life in America.

36. Moore, Gilbert, A Special Rage, New York, Harper \& Row, 1971.

This book is one of many books devoted in full or in part to the Newton trial and members of the legal profession.

37. Neiderhaffer, A., Behind the Shield, Garden City, New Jersey, Doubleday, 1967 .

38. Ploski, Harry A., and Roscoe C. Brown, The Negro Almanac: The Negro--His Part in America, New York, Belweather Pub., 1967.

An extraordinary reference book that contains a wealth of information on Black Americans. An overview of Negro history, statistical data on the Negro, and biographies of famous Black Americans.

39. Rose, Peter L., Slavery and Its Aftermath, New York, Athenton Press, 1970.

An excellent collection of articles written by Black professionals concerning the significance of African culture on the Black

family. This book gives a detailed description of the impact of slavery, the retention of Africanism, and the realities of community and family life of Blacks in urban ghettos and the rural South.

40. Scharche, Don A., The Panther Paradox: A Liberal Dilemma, New York, David McKay Co., Inc., 1970.

This book examines a liberal's conception of the Black Panther Party, its objectives, its leaders, and its members. It is a critical examination done by a White liberal author whose racism is apparent from the beginning of the book.

41. Sithale, Nelabaringi, African Nationalism, London, Oxford University Press, 1968. 
The author examines the patterns of criminal injustices imposed by White europeans on native Africans. A relationship is drawn between these patterns and those imposed on American Blacks by White Anericans.

42. Sloans, Irving, Blacks in America: 1492-1970, Ocean Publications, Inc., New York, 1971.

A chronological collection of true facts about Black history and famous Black Americans.

43. Thurow, Lester, Poverty and Discrimination, Washington, D.C., Brookings, 1969.

The book discusses the problem of poverty in terms of discrimination on the labor market.

44. Walters, Raymond, Negroes and the Great Depression, Connecticut, Greenwood Publishing Co., 1970.

This book examines the economic conditions of Blacks during the depression; the employment market and labor organizations.

45. Washington Jr., Joseph B., Black and White Power Segregation, Boston: Beacon Press, 1971.

This book reviews the current establishment of American government and concludes that from a Black and ethnic point of view that history of White power and civil rights so far has been largely one of segregation.

46. Williams, Eric, Capitalism and Slavery, New York, Pittman Co., 1966.

This book explores the economics of slavery in American, and how it contributed to American capitalism.

47. Young, Richard P., Roots of Rebellion: The Evolution of Black Politics and Protest Since World War II, New York: Harper \& Row, Publishers, 1970.

This book gives the reader an astonishing explanation of the growth and development of Black radicalism in America during the early 1960's.

48. Zinn, Howard, SNCC: The New Abolitionists, Boston: Beacon Press, 1965.

Provides a glimpse of SNCC leaders in action, and suggests the quality of their contributions to America. 


\section{Bibliography}

for Social Work Practice Sequence

1. Amy, Jacques, and Frank Garvey, The Philosophy and Opinion of Mareus Garvey, Cass and Co., Ltd., 1967.

Included in this book is a selection of Garvey's speeches which best illustrate the dynamics of his ideology on present-day Africa, the Negro, and Black Nationalism. Garvey was a Black West Indian who spent most of his active life in the U.S.A. involved in early attempts to achieve some measure of justice and recognition for the Black man.

2. Be11, Inge P., Core and the Strategy of Non-Violence, New York, Random House, 1968.

A study of the strategy of non-violence used by Core, and how massive violence of bigotry became the killer of passive resistance emphasizing that violence is "as American as cherry pie."

3. Chambers, Bradford, Chronicles of Protest, New York, N.Y., Parent Magazine Press, 1968.

A collection of documents that are major milestones in the route from slavery to Black power. Included are ideologies of Black leaders past and present. An excellent resource that reviews various tactics used by Black leaders to combat White racism.

4. Foreman, James, The Making of Black Revolutionaries, New York, MacMillan and Co., 1972.

The author describes some of the oppressive conditions that mold one into being a revolutionary.

5. Fox, E1ton C., Contemporary Black Leaders, New York, Dodd, Mead and Co., 1970 .

This book discusses the myths and misconceptions about Black leaders and Black organizations.

6. Franklin, John Hope and Isadore, The Negro in the Twentieth Century America, New York, Vintage Book, 1967.

An excellent collection of documents on the Black man's struggle for equality in this country. 
7. Frazier, Thomas R., Afro-American History: Primary Sources, New York, San Francisco, Harcourt, Brace, World, Inc., 1970.

This study is an introduction to the history of Afro-Americans through the use of historical documents. A careful attempt has been made to represent the wide range of Black life and thought that has contributed to the development of Black America. Material is arranged chronologically from the colonia period to the present, with description of Black life, statements of Black leaders, and position papers of Black organizations.

8. Genovese, Eugene D., The Political Economy of Slavery, New York, Pantheon, 1965.

A valuable collection of studies on the economic reasons for slavery in America.

9. Gitterman, Alex and Alice Schayfer, "The White Professional and the Black Client," Social Casework, Vo1. 53, No. 5, May, 1972.

An excellent article that explores the impact of racism on the helping proféssion.

10. Haskins, James, Profiles in Black Power, New York, Doubleday and Co,, Inc., 1972.

Examines the meaning of the slogan "Black Power" as defined by eleven Black leaders who contributed to its development.

11. Hawley, Willis, D., Blacks and Metropolitan Government: The Stakes of Reform, Institute of Government Studies, 1972 .

Examines the institutions that shape public policies for Black urban Americans.

12. Hmamu, Amiro Baraba, African Congress: A Documentary of the First Pan-African Congress, New York, Williana Lowow and Co., 1973.

A review of the Pan-African Congress Workshop reports held September, 1970. Included are speeches, resolutions, and discussions by Black leaders concerning political liberation, . Community organization, law, creativity, justice, education, technology, history, and Black economics.

13. King, Martin L., Strive Toward Freedom: The Montgomery Story, New York, Harper and Row Publishers, Inc., 1964. 
An account of a few years that changed the lives of Black Americans who took to heart the principles of non-violence, who learned to fight for their rights with the weapon of love. Historically, the story is known as the Montgomery Bus Boycott.

14. Leigh, James W. "Ethnic Content in Field Instruction," A report presented at the Western Interstate Commission on Higher Education (WICHE) Workshop on Minority Ethnic Content in the Social Work Curriculum, Idyllwild, California, December, 1971.

A useful resource paper which includes valuable material on the integration of Black content into the field practicum.

15. McCord, Willlam; Howard, John; Friedberg, Bernard; Harwood, Edwin, Life Styles in the Black Ghetto, New York, W.W. Norton. and Co., 1969 .

This book examines the psychological responses to the "White estab1ishment."

16. Meier, August and Elliott Rudwich, Core: A Study in the Civil Rights Movement, 1942-1968, New York, Oxford Untversity Press, 1973.

A study of the rise and decline of one of the leading Civil Rights organizations of the twentieth century, giving special attention to tactics, strategies, ideologies, and organizational structure, as well as Core's major campaigns. This study also places Core in the context of the larger Civil Rights movement and analyzes its interrelationships with other Black protest organizations.

17. Newton, Huey P., Revolutionary Sulcide, New York, Harcourt, Brace, Jovanovich \& Co., 1973.

An inside look at the Black Panther Party, its leaders, and its ideology.

18. Odom, E. O., Black Nationalism: The Search. for an Identity in America; University of Chicago Press, 1962.

This book is primarily a study of Black Muslims in America. An excellent view of organizational strategies developed by the Black community for survival in a dysfunctional society.

19. Parks, Gordon, Born Black, Philadelphia, J. B. Lippincott \& Co., 1971.

Parks clearly states the realities of Black family life, Black leadership and Black organizations in their struggle for existence and survival in the U.S.A. 
20. Shannon, Barbara E., Implications of White Racism for Socia1 Work Practice, Social Casework, Vo1. 51, No. 5, May, 1970, pp. 270-6.

The author presents an astonishing discussion on the implications of White racism on the social work profession. She briefly describes the negative steredtyping of B1ack as one of the most common manifestations of White racism in social work education.

21. Warren, Roland L., Politics and the Ghetto, New York, Atherton Press, 1969.

This book examines decision-making in America's ghettos. It examines the complex forces and counter-forces whose aggregate results are inferior housing, inadequate education, and involuntary segregation, found in the Black ghetto.

22. Woodward, C. Vann, The Strange Career of Jim Crow, New York, Oxford University Press, revised 1966.

A study that deals with the beginning of discrimination in the South after the Civil War:

$$
\text { -- Papers -- }
$$

23. Better, Shirley, "The Roles of the Black Social Worker in the Black Community: New Approaches to Community Planning," American Public Welfare Journal, November, 1972.

This paper examines issues of effective community planning in the Black Community and the role of the Black social worker.

24. Leigh, James W., "Ethnic Content in Field Instruction," A paper presented at the WICHE Workshop on Faculty Development: Ethnic Content in the Social Work curriculum, in Idyllwild, California, November 10, 1971.

A useful resource paper which includes valuable material on the integration of Black content into the field practicum.

25. Olive, Petro and Betty French,"The Black Client's View of Himself," Social Casework, October 1972, Vol. 53, No.8, pp.466-474.

26. Sanders, Charles L., "Growth of the Association of Black Social Workers," Socia1 Casework, Vo1. LI, No. 5, May, 1970, pp. 277-284.

An interesting article on the organizational efforts and strategies of a national Black organization of professional social workers. 
27. Stiles, Evelyn, and Susan Donner, Jean Giovannone, Elizabeth Lochte, and Rebecca Reetz, "Hear it Like it Is," Social Casework, Vo1. LIII, No. 5, May, 1970, pp. 292-299.

An article on how race sensitivity affects the treatment of Black cllents. An excellent article on the funky realities of social work in the Black community. 